\title{
Evaluation of suitable reference genes for normalization of quantitative real-time PCR analysis in rice plants under Xanthomonas oryzae pv. oryzae--infection and melatonin supplementation
}

\author{
Xian Chen ${ }^{1,2}$, Pedro Laborda ${ }^{3}$, Yan Dong ${ }^{1}$ and Fengquan Liu* ${ }^{1 *}$
}

\begin{abstract}
Exogenous melatonin (MT) was found to be an interesting tool for enhancing the resistance of rice to Xanthomonasoryzaepv. oryzae (Xoo)-caused bacterial blight (BB). However, the accurate comparison of the expression levels across samples was a challenging task. In this work, the stability of 10 common used housekeeping genes under Xoo-infection and MT supplementation in rice was analyzed using quantitative real-time PCR (qRT-PCR), and algorithms geNorm, NormFinder and BestKeeper. Our results indicated that most reference genes remained stable in Xoo-infected rice plants, while a number of reference genes were affected by MT supplementation. Among all studied genes, the transcript levels of 18S(185 ribosomal $R N A$ ) and UBC (Ubiquitin-conjugating enzyme E2) remained unaltered by Xoo infection, while UBC and UBQ5(Ubiquitin 5) were the most stable genes when examining simultaneous Xoo-infection and MT supplementation, demonstrating that UBC is a suitable reference gene for qRT-PCR data normalization in rice under Xoo-infection and MT supplementation.
\end{abstract}

Keywords: Rice, Xanthomonas oryzae pv. oryzae, Melatonin, qRT-PCR, Reference genes

\section{Introduction}

Rice is one of the most important crops worldwide, providing essential food supply to most of the world's population. However, rice is highly susceptible to a wide range of pathogens that limit its production and quality. Among rice pathogens, Xanthomonas oryzae pv. oryzae $(X o o)$, the causal agent of bacterial blight (BB), is a member of $\gamma$-proteobacteria, and is able to invade plant through wounds and hydathodes to colonize the xylem (White and Yang 2009). This pathogen can rapidly spread through the vascular system, leading to systemic infection (Yuan et al. 2010). Its pathogenicity is partially

\footnotetext{
*Correspondence: fqliu20011@sina.com

1 Institute of Plant Protection,Jiangsu Key Laboratory for Food Quality and

Safety-State Key Laboratory Cultivation Base of Ministry of Science and

Technology, Jiangsu Academy of Agricultural Sciences, Nanjing 210014, PR

China

Full list of author information is available at the end of the article
}

dependent on a type III protein secretion system (TTSS) (Pfeilmeier et al. 2016). During the early infection stages, the expression levels of 541 genes were altered in response to Xoo in susceptible rice JG30 (Tariq et al. 2019), while the expression levels of 115 genes were altered in resistant hybrid rice Y73 in response to Xoo infection, which corresponds to $0.22 \%$ of the rice genome (Wang et al. 2012). Many of these differential expressed genes (DEGs) were related to signaling, transcription and metabolic processes.

Melatonin ( $N$-acetyl-5-methoxytryptamine) consists of an indole structure with low molecular weight, and has been found in a wide range of plant species (Wang et al. 2020). MT regulates gene expression in many cellular and physiological aspects ( $\mathrm{Li}$ et al. 2019b). It is reported that 457 differentially expressed genes were identified in response to salt stress under MT supplementation (Liang

(c) The Author(s). 2020 Open Access This article is licensed under a Creative Commons Attribution 4.0 International License, which permits use, sharing, adaptation, distribution and reproduction in any medium or format, as long as you give

appropriate credit to the original author(s) and the source, provide a link to the Creative Commons licence, and indicate if changes were made. The images or other third party material in this article are included in the article's Creative Commons licence, unless indicated otherwise in a credit line to the material. If material is not included in the article's Creative Commons licence and your intended use is not permitted by statutory regulation or exceeds the permitted use, you will need to obtain permission directly from the copyright holder. To view a copy of this licence, visit http://creativecommons.org/licenses/by/4.0/. 
et al. 2015). Those DEGs were associated to defense responses, protein phosphorylation, hormone-mediated signaling pathways and metabolic processes. Interestingly, Xoo-infection increased the mRNA expression level of OsAMT1, one of the key genes in MT biosynthesis (Wei et al. 2016). Recently, our research group demonstrated that melatonin can enhance rice resistance against Xoo by increasing the expression of pathogensis-related genes (PRs), and showed antibacterial activity against Xanthomonas spp. (Chen et al. 2018, 2019, 2020).

qRT-PCR is a remarkably robust technique used for the quantification of gene expression in different samples (Bustin and Nolan 2017). However, the accuracy of quantitative analysis maybe influenced by several biasing factors, such as sample type, sample integrity and experimental conditions (Shen et al. 2010; Yang et al. 2018). Therefore, normalization of gene expression using stable internal standards, also called housekeeping genes or reference genes, is critical for the accurate comparison of gene expression across samples (Robledo et al. 2014). Theoretically, reference genes should remain stable under different experimental conditions and may show the same mRNA level in all type of cells and tissues. However, there is no universal internal standard gene that fulfills completely this criterium (Sundaram et al. 2019). Hence, the validation of the expression stabilities of reference genes is necessary for the accurate acquisition of qRT-PCR data. In this work, we have investigated for the first time the expression stability of 10 candidate reference genes, including $18 S$ ribosomal RNA (18S), 25 S ribosomal RNA (25S), Ubiquitin 5 (UBQ5), Ubiquitin 10 (UBQ10), Actin (ACT), $\beta$-Tubulin ( $\beta$-TUB), Eukaryotic elongation factor 1-alpha

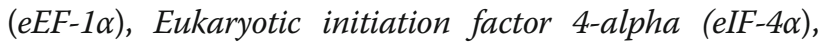
$U B C$ and Glyceraldehyde-3-phosphate dehydrogenase (GAPDH), under Xoo-infection and MT supplementation (Jain et al. 2006; Kim et al. 2003; Li et al. 2010). The final outcome of this feasible study will benefit further quantifications of gene expression by qRT-PCR and RNA-seqbased transcriptomic studies in rice.

\section{Materials and methods Reagents}

MT was purchased from Sigma-Aldrich (St. Louis, USA). Analytical grade methanol was purchased from Sinopharm Chemical Reagent (Shanghai, China). TRIzol was obtained from Invitrogen (Carlsbad, USA). SYBR Green PCR Master Mix and cDNA Synthesis kits were purchased from Takara Bio (Shiga, Japan). Ultra pure water was purified in a Milli-Q water purification system (Millipore,Burlington, USA).

\section{Plant and bacterial strains}

Rice seeds (O. sativa cv. Nipponbare) were grown in a growth chamber with a photon flux density of $200 \mu \mathrm{mol} /$ $\mathrm{m}^{2} \mathrm{~s}^{1}$ under alternating $30^{\circ} \mathrm{C} / 12 \mathrm{~h}$ dark and $28^{\circ} \mathrm{C} / 12 \mathrm{~h}$ light cycles. The seedlings were cultured in $1 \mathrm{~L}$ of IRRI nutrient solution $\quad\left(28.6 \mathrm{mg} / \mathrm{L} \quad \mathrm{NH}_{4} \mathrm{NO}_{3}, \quad 40.5 \mathrm{mg} / \mathrm{L}\right.$ $\mathrm{MgSO}_{4} \cdot 7 \mathrm{H}_{2} \mathrm{O}, 36.7 \mathrm{mg} / \mathrm{L} \mathrm{CaCl}_{2} \cdot 2 \mathrm{H}_{2} \mathrm{O}, 89.3 \mathrm{mg} / \mathrm{L} \mathrm{K}_{2} \mathrm{SO}_{4}$, $50.3 \mathrm{mg} / \mathrm{L} \mathrm{Na} \mathrm{NPO}_{4} \cdot 2 \mathrm{H}_{2} \mathrm{O}, 1.2 \mathrm{mg} / \mathrm{L} \mathrm{H}_{3} \mathrm{BO}_{3}, 11.6 \mathrm{mg} / \mathrm{L}$ $\mathrm{Na}_{2} \mathrm{EDTA} \cdot 2 \mathrm{H}_{2} \mathrm{O}, \quad 8.7 \mathrm{mg} / \mathrm{L} \quad \mathrm{FeSO}_{4} \cdot 7 \mathrm{H}_{2} \mathrm{O}, \quad 9.25 \mathrm{mg} / \mathrm{L}$ $\left(\mathrm{NH}_{4}\right)_{6} \mathrm{MoO}_{24} \cdot 4 \mathrm{H}_{2} \mathrm{O}, 43.8 \mathrm{mg} / \mathrm{L} \mathrm{ZnSO}_{4} \cdot 7 \mathrm{H}_{2} \mathrm{O}, 38.8 \mathrm{mg} / \mathrm{L}$ $\mathrm{CuSO}_{4} \cdot 5 \mathrm{H}_{2} \mathrm{O}$ and $1.8 \mathrm{mg} / \mathrm{L} \mathrm{MnCl}_{2} \cdot 4 \mathrm{H}_{2} \mathrm{O}$ ) for 5 weeks. Xoo strain PXO99 was grown in liquid nutrient broth (NB) medium $(5 \mathrm{~g} / \mathrm{L}$ polypeptone, $3 \mathrm{~g} / \mathrm{L}$ beef extract, 10 $\mathrm{g} / \mathrm{L}$ sucrose and $1 \mathrm{~g} / \mathrm{L}$ yeast extract, $\mathrm{pH} 7.0-7.2)$ or on nutrient agar (NA) medium (NB with $15 \mathrm{~g} / \mathrm{L}$ agar).

\section{MT treatment and bacterial pathogen inoculation}

Five-week-old rice plants were used for the experiments. The plant roots were submerged in water containing MT $(0$ and $20 \mu \mathrm{g} / \mathrm{mL})$, and the plant leaves were inoculated with water or Xoo $\left(\mathrm{OD}_{600}=1.0\right)$. Xoo was cultured in NB medium for $24 \mathrm{~h}$ with shaking at $180 \mathrm{rpm}$ at $28^{\circ} \mathrm{C}$. The bacterial cells were centrifuged for $10 \mathrm{~min}$ at $6000 \mathrm{rpm}$ and $4{ }^{\circ} \mathrm{C}$, and suspended in water to $\mathrm{OD}_{600}=$ 1.0. Rice leaves were inoculated with PXO99 using the leaf clipping method (Kauffman et al. 1973), following the same conditions previously reported by Laborda et al. (2020). Four parallel treatment conditions were studied: 1 . rice leaves were treated with water, while the plant roots were cultivated in water in the absence of MT (water group); 2. rice leaves were inoculated with $X o o$, and the plant roots were submerged in water in the absence of MT (Xoo group); 3. rice leaves were inoculated with water, and the plant roots were submerged in an aqueous solution containing $20 \mu \mathrm{g} / \mathrm{mL}$ melatonin (MT-water group); and 4. rice leaves were inoculated with $\mathrm{Xoo}$, and the plant roots were submerged in an aqueous solution containing $20 \mu \mathrm{g} / \mathrm{mL}$ melatonin (MTXoo group). Twelve hours after inoculation of the pathogen, the infected leaves were collected for RNA extraction.

\section{RNA isolation and CDNA synthesis}

Specific primersfor candidate reference genes $A C T, e E F$ $1 \alpha$, eIF-4 $\alpha, G A P D H, U B C, U B Q 5, U B Q 10, \beta-T U B, 18 S$ and $25 S$ were designed using Primer 5 (version 5.0). The gene sequences were obtained from the rice genome annotation project (RGAP; http://rice.plantbiology.msu. edu/) database (Table 1). The total RNA from rice leaves was extracted using the TRizol reagent method (Invitrogen, Germany). Total RNA extraction and quality test were determined by UV spectrophotometric analysis and $2 \%$ agarose gel electrophoresis, and pure RNA should yield an A260/A230 ratio of around 2 or slightly above. To eliminate the genomic DNA, $2 \mu \mathrm{g}$ of total RNA was treated with $1 \mu \mathrm{Lg}$ DNA Eraser (Takara, Japan). Finally, cDNA was synthetized using a Primerscript ${ }^{\mathrm{Tm}} \mathrm{RT}$ reagent 
Table 1 List of the internal reference genes and the amplification specifications in qRT-PCR

\begin{tabular}{|c|c|c|c|c|c|}
\hline No & $\begin{array}{l}\text { Gene } \\
\text { symbol }\end{array}$ & Gene name & $\begin{array}{l}\text { GenBank accession } \\
\text { No. }\end{array}$ & Primer sequence $\left(5^{\prime}-3^{\prime}\right)$, Fwd // Rev & $\begin{array}{l}\text { Amplicon size } \\
\text { (bp) }\end{array}$ \\
\hline 1 & 185 & $18 \mathrm{~S}$ ribosomal RNA & AF069218.1 & $\begin{array}{l}\text { CTACGTCCCTGCCCTTTGTACA// } \\
\text { ACACTTCACCGGACCATTCAA }\end{array}$ & 213 \\
\hline 2 & $25 S$ & $25 \mathrm{~S}$ ribosomal RNA & M11585.1 & $\begin{array}{l}\text { AAGGCCGAAGAGGAGAAAGGT// } \\
\text { CGTCCCTTAGGATCGGCTTAC }\end{array}$ & 238 \\
\hline 3 & $\mathrm{ACT}$ & Actin & AB047313.1 & $\begin{array}{l}\text { CAGCCACACTGTCCCCATCTA// } \\
\text { AGCAAGGTCGAGACGAAGGA }\end{array}$ & 184 \\
\hline 4 & $\beta-T U B$ & $\beta-$ tubulin & D30716.1 & $\begin{array}{l}\text { GCTGACCACACCTAGCTITGG// } \\
\text { AGGGAACCTTAGGCAGCATGT }\end{array}$ & 224 \\
\hline 5 & eEF-1a & Eukaryotic elongation factor 1 - alpha & GQ848073.1 & $\begin{array}{l}\text { TTCACTCTTGGTGTGAAGCAGAT// } \\
\text { CTTCCTTCACGATTTCATCGTAA }\end{array}$ & 228 \\
\hline 6 & elF-4a & Eukaryotic initiation factor 4 - alpha & AB046414.1 & $\begin{array}{l}\text { TTGTGCTGGATGAAGCTGATG// } \\
\text { GGAAGGAGCTGGAAGATA } \\
\text { TCATAGA }\end{array}$ & 236 \\
\hline 7 & UBC & Ubiquitin-conjugating enzyme E2 & AK059694 & $\begin{array}{l}\text { CCGTTTGTAGAGCCATAATTGCA// } \\
\text { AGGTTGCCTGAGTCACAGTTAAGTG }\end{array}$ & 188 \\
\hline 8 & UBQ-5 & Ubiquitin 5 & AK061988.1 & $\begin{array}{l}\text { ACCACTTCGACCGCCACTACT// } \\
\text { ACGCCTAAGCCTGCTGGTT }\end{array}$ & 167 \\
\hline 9 & UBQ-10 & Ubiquitin 10 & AK101547 & $\begin{array}{l}\text { TGGTCAGTAATCAGCCAGTTTGG// } \\
\text { GCACCACAAATACTTGACGAACAG }\end{array}$ & 192 \\
\hline 10 & GAPDH & $\begin{array}{l}\text { Glyceraldehyde - } 3 \text { - phosphate } \\
\text { dehydrogenase }\end{array}$ & GQ848049.1 & $\begin{array}{l}\text { AAGCCAGCATCCTATGATCAGATT// } \\
\text { CGTAACCCAGAATACCCTTGAGTTT }\end{array}$ & 189 \\
\hline
\end{tabular}

kit (Takara, Japan). qRT-PCR was performed with diluted first strand cDNA, specific gene primers, and SYBR Green PCR Master MIX (TakaRa, Japan). All samples were diluted 10 times and were run on a LightCycler ${ }^{\circ} 480$ Instrument II Real Time PCR system (Roche, Switzerland). The PCR amplification program consisted of 1 cycle of $95^{\circ} \mathrm{C}$ for $30 \mathrm{~s}$ followed by 45 cycles of $95^{\circ} \mathrm{C}$ for $5 \mathrm{~s}$, and $60^{\circ} \mathrm{C}$ for $30 \mathrm{~s}$. Individual well fluorescence data were generated at the end of PCR cycles, with $95^{\circ} \mathrm{C}$ for $5 \mathrm{~s}$ followed by $60{ }^{\circ} \mathrm{C}$ for60s. The experiments were repeated at least three times using different biological samples.

\section{qRT-PCR assay and expression stability analysis}

Total RNA concentration of each sample was determined with a NanoDrop spectrophotometer by using the RNA application (Eppendorf, BiophotometerPlus Spectrophotometer, Germany). Efficiency of amplification curves (E value), cycle threshold $(\mathrm{Ct})$ and correlation coefficient $\left(R^{2}\right)$ were determined using LinReg PCR software (http://LinRegPCR.nl/). In LinReg analysis, efficiency of amplification value was set to 2.0. The expression stability of the candidate reference genes was analyzed using the BestKeeper version (http://www. gene-quantification.de/bestkeeper.html), NormFinder 0953 (http://moma.dk/normfinder-software) and geNorm (http://medgen.ugent.be/jvdesomp/genorm/) following the developer's instructions. For BestKeeper analysis, the average $\mathrm{Ct}$ value from each sample were input directly. The relative expression of each target gene was calculated using the $2^{-\Delta \Delta C t}$ method. Before inputting into the software program of Norm Finder and geNorm, the raw $\mathrm{Ct}$ values of each gene were converted into relative quantities and the highest relative expression was set to 1.0 for each reference gene. Through the geNorm analysis, the ranking of tested reference genes was based on their expression stability value $(M)$ as the average pairwise variation $(\mathrm{V})$ between a particular gene to all other candidate genes.

\section{Results and discussion Total RNA extraction and RNA quality assessment}

In plant leaves, the isolation of high-purity RNA with sufficient quantity is essential to study the stability of reference genes. To achieve this goal, total RNA from four groups (water, Xoo, MT-water and MT-Xoo) were extracted and isolated by using the TRizol reagent method (Chomczynski and Mackey 1995). The concentration and purity of RNA from different samples were determined using Eppendorf Biophotometer plus and agarose gel electrophoresis. In the eppendorf Biophotometer plus analysis, the values of A260/A280 of the isolated RNA were close to 2.0. The overall quality of total RNA was further assessed by agarose gel electrophoresis assay. As shown in Fig. 1, the two ribosomal components (25S and 18S) were readily identified in the agarose gel without obvious degradation (Srivastava et al. 2012). The isolated RNA showed five bands (Fig. 1). The results suggested that 


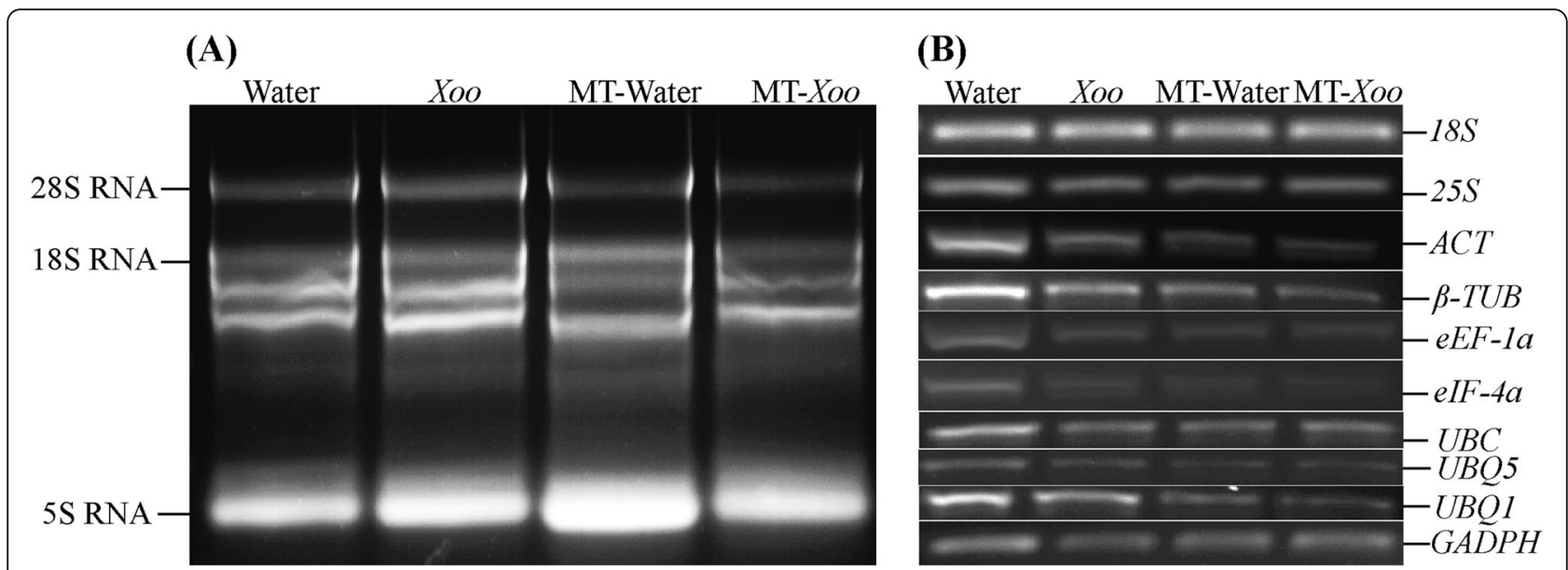

Fig. 1 Agarose gel electrophoresis. a Agarose gel of total RNAs extracted from groups of water, Xoo, MT-water or MT-Xoo infected rice plant leaves. $\mathbf{b}$ Agarose gel of PCR products from candidate reference genes

the total RNA had good integrity and purity, and could be used for further studies.

\section{Optimization of qRT-PCR amplification conditions for candidate reference genes}

After synthesis of the first-strand cDNA from the four treatment groups (water, Xoo, MT-water and MT-Xoo), the specificity and PCR amplification conditions for the 10 candidate reference genes were tested by PCR. The cDNA with length from 167 to 238 base pairs containing normal bases were amplified. As shown in the agarose gel of Fig. 2, all 10 pairs of primers successfully produced a unique amplicon with the target product lengths. Then, specificity and amplification efficiency of the primers for the 10 candidate reference genes was tested by using qRT-PCR (Table 2). A single peak for each primer set was observed in the amplification plot, indicating that all candidate primers produced unique amplicon without any primer dimers or other nonspecific amplification products (Fig. 2). The obtained results indicated that all primers had good specificity and could be used for the gene stability assay.

It is well known that amplification efficiency plays a key role in the accuracy and reliability of reference genes, while the challenge of determining amplification efficiency is known to be a predominant aspect of implementing qRT-PCR (Rutledge and Stewart 2008). Here, the amplification efficiency (E) and the correlation coefficient $\left(R^{2}\right)$ values were calculated using the LinRegPCR software. The $\mathrm{E}$ values of the candidate reference genes

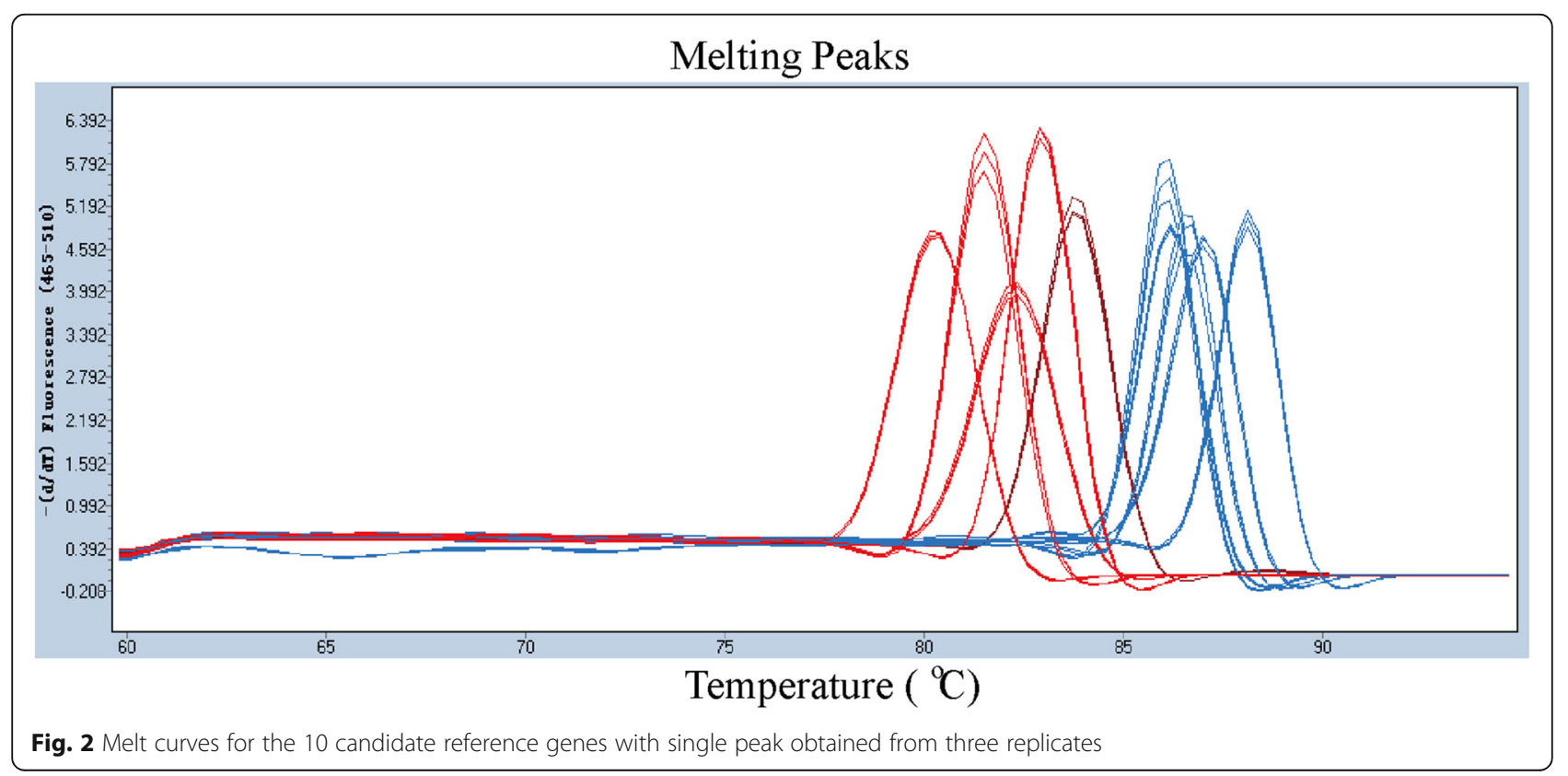


Table 2 Mean Ct values and amplification efficiency of candidate internal reference genes

\begin{tabular}{|c|c|c|c|c|c|c|c|c|c|c|}
\hline \multirow{2}{*}{$\begin{array}{l}\text { Gene } \\
\text { symbol }\end{array}$} & \multicolumn{2}{|l|}{ Water } & \multicolumn{2}{|l|}{ Xoo } & \multicolumn{2}{|l|}{ MT-Water } & \multicolumn{2}{|l|}{ MT-XoO } & \multirow{2}{*}{$\begin{array}{l}\text { PCR } \\
\text { efficiency }\end{array}$} & \multirow[t]{2}{*}{$R^{2}$} \\
\hline & Mean $(\mathrm{Ct})$ & $\mathrm{SD}( \pm \mathrm{Ct})$ & Mean $(\mathrm{Ct})$ & $\mathrm{SD}( \pm \mathrm{Ct})$ & Mean $(\mathrm{Ct})$ & $\mathrm{SD}( \pm \mathrm{Ct})$ & Mean $(\mathrm{Ct})$ & $\mathrm{SD}( \pm \mathrm{Ct})$ & & \\
\hline 185 & 7.509022 & 0.057528 & 7.541728 & 0.151079 & 7.364891 & 0.140951 & 7.251798 & 0.063727 & 1.9935 & 0.99725 \\
\hline $25 S$ & 9.759871 & 0.102621 & 9.831956 & 0.09594 & 9.436561 & 0.210717 & 9.561671 & 0.235636 & 1.91625 & 0.999 \\
\hline $\mathrm{ACT}$ & 18.79102 & 0.221776 & 19.12131 & 0.191417 & 18.35688 & 0.266497 & 19.43089 & 0.171603 & 1.83575 & 0.9715 \\
\hline$\beta$-TUB & 28.43714 & 0.176962 & 28.56222 & 0.206912 & 28.43466 & 0.369246 & 28.94232 & 0.482744 & 1.8635 & 0.99975 \\
\hline eEF1-a & 17.3651 & 0.059846 & 17.68532 & 0.065735 & 17.86457 & 0.250979 & 18.01716 & 0.289779 & 1.8835 & 0.99975 \\
\hline elF-4a & 20.72344 & 0.109694 & 20.98324 & 0.058178 & 21.19292 & 0.312464 & 21.439 & 0.314081 & 1.87125 & 0.99975 \\
\hline UBC & 21.93981 & 0.165087 & 22.1574 & 0.05665 & 22.20476 & 0.223596 & 22.37866 & 0.215301 & 1.87825 & 0.9995 \\
\hline UBQ5 & 17.94632 & 0.099612 & 18.21766 & 0.077023 & 18.40336 & 0.207519 & 18.63075 & 0.212819 & 1.8825 & 0.99975 \\
\hline UBQ10 & 18.2794 & 0.152598 & 18.5252 & 0.088786 & 18.87545 & 0.2442 & 19.2134 & 0.262454 & 1.885 & 0.99975 \\
\hline GADPH & 26.33569 & 0.183057 & 26.26842 & 0.216105 & 26.69255 & 0.298437 & 26.88369 & 0.329891 & 1.86925 & 0.99925 \\
\hline
\end{tabular}

varied from 0.97 for $A C T$ to 0.9998 for $U B Q 10$, and the $\mathrm{R}^{2}$ values of candidate reference genes ranged from 1.8358 to 1.9935 (Table 2). The reactions provided accurate linear relationships, with $R^{2}>0.99$ and $\mathrm{E}$ value close to 2.0. The overall variability of candidate reference genes under different treatment conditions was assessed by the average values of $\mathrm{Ct}$ (cycle threshold) and SD (standard deviation) (Table 2). LinRegPCR analysis determined the average $\mathrm{Ct}$ values of the 10 candidate reference genes, and the minimum $\mathrm{Ct}$ value was found for the $18 S$ gene $(7.50 \pm 0.05)$, indicating that this gene showed the highest transcript abundance, whereas the lowest transcript abundance was found for the $\beta-T U B$ gene $(28.44 \pm 0.18)$. The $\mathrm{Ct}$ values of $e E F-1 a$ and $U B Q 5$ genes were relatively constant (17.36-18.01 and 17.9418.63, respectively), withlow SD values throughout the infection-groups (Xoo and MT-Xoo) and mock inoculated-groups (water and MT-water). For the rest eight candidate genes, the mean $\mathrm{Ct}$ values ranged from 7.51 to 28.43 in the water group, from 7.54 to 28.56 in the Xoo group, from 7.36 to 28.36 in the MT-water group, and from 7.25 to 28.94 in the MT-Xoo group. The mean $\mathrm{Ct}$ values of $18 \mathrm{~S}$ changed over a narrow range from $7.25 \pm 0.06$ to $7.59 \pm 0.057$ in mock inoculated (water and MT-water) and infection (Xoo and MT-Xoo) groups (Table 2).

The gene of $U B C$ has been commonly used as reference gene in rice under pathogen infection (Bi et al. 2019; Li et al. 2019). Previous studies indicated that the mean $C t$ values for $U B C$ were $22.53,22.55$ and 22.43 in virus-free rice plants, Rice Black-Streaked Dwarf Virus (RBSDV)-infected rice plants and Rice Strip Virus (RSV)-infected rice plants, respectively (Shen et al. 2014). In agreement with that work, the mean $C t$ values of $U B C$ were 21.94, 22.16, 22.21 and 23.38 in the water, Хoo, MT-water, and MT-Xoo groups, respectively.

\section{Evaluation of expression stability of reference genes for qRT-PCR}

It was reported that some reference genes, such as $T U B$ and $A C T$, were associated with low stability in rice plants (Jain et al. 2006; Zhao et al. 2019). Using unstable reference genes may lead to large errors in normalization of reference genes, resulting in incorrect interpretations (Sheshadri et al. 2018). In order to identified the most stable reference genes under MT supplementation in presence and absence of Xoo infection in rice plants, three commonly used algorithms for qRT-PCR normalization, including geNorm, NormFinder and BestKeeper, were employed (Vandesompele et al. 2002; Andersen et al. 2004; Pfaffl et al. 2004). The geNorm algorithm provides the stability value $(M)$ for each candidate gene based on the pairwise standard deviation of cycle quantification $(\mathrm{Cq})$ value. In the geNorm algorithm, the lower is the $M$ value, the higher is the expression stability of the studied gene. The NormFinder evaluates the stability value of all tested candidate genes based on the variations between intra-group and intergroup. BestKeeper determines the stability value of the candidate reference genes based on the standard deviation (SD) and coefficient of variance (CV).

In our work, the default value was fixed at $M=0.5$ in the geNorm program (Silveira et al. 2009). Thus, the candidate reference genes with $M$ value lower than 0.5 were considered as genes with stable expression, whereas the genes with $M$ value higher than 1.5 were excluded directly. In the water treatment group, the expression stability of the 10 candidate genes ranked as follows: $U B C=18 S>\beta-T U B>A C T>G A P D$ $H>e I F-4 \alpha>U B Q 5>e E F-1 \alpha>U B Q 10>25 S$. Our study identified that $U B C$ and $18 S$ genes had the lowest $M$ values $(M=0.07)$, while $25 S$ had the highest $M$ value $(M=0.21)$, indicating that $U B C$ and $18 S$ were the most stably expressed genes for this treatment group (Fig. 4a). In the Xoo group, the expression stability of the 10 candidate genes ranked as 
follows: $U B Q 10=U B Q 5>e E F-1 \alpha>e I F-4 \alpha>18 S>\beta-T U B>$ $A C T>25 S>G A P D H>U B C . \quad U B Q 10$ and $U B Q 5$ genes showed the lowest $M$ value $(M=0.04)$ (Fig. $4 \mathrm{~b})$, while $25 S$ ranked as the least stable $(M=0.19)$. In the MT-water group, the expression stability of the 10 candidate genes ranked as follows: $e E F-1 \alpha=U B C>U B Q 10>U B Q 5>25 S>e I F-4 \alpha>$ $G A P D H>A C T>18 S>\beta-T U B$. The $\beta-T U B$ gene showed the highest $M$ value $(M=0.13)$, while $e E F-1 \alpha$ and $U B C$ were found the most stable genes $(M=0.06)$ for this treatment group (Fig. 4c). In the MT-Xoo group, the expression stability of 10 candidate genes ranked as follows: $e E F-1 \alpha=e I F-4 \alpha>$ $U B Q 5>U B C>\beta-T U B>U B Q 10>A C T>G A P D H>18 S>$

$25 S$, demonstrating that genes $e E F-1 \alpha$ and $e I F-4 \alpha(M=0.05)$ were the most stable (Fig. 3d). In contrast, the $25 S$ gene was ranked as least stable, with the highest $M$-value $(M=0.13)$. The obtained results suggested that all the 10 candidate genes were acceptable as reference genes $(M<0.5)$.

The optimal number of candidate reference genes required for normalization factors (NF) was also determined by geNorm, by calculating the pairwise variation $(\mathrm{V} / \mathrm{n}+1)$ between two sequential normalization factors. The V-value cut-off was set at 0.15 in this case. The results showed that all $\mathrm{V}$ values of the selected genes were less than 0.15 (Fig. 4e and f), in agreement with the stability results.
In the NormFinder analysis the candidate reference gene with the lowest stability value (SV) have the highest stable expression. As shown in Fig. 4a, the expression stability of the 10 candidate genes in the water group ranked as follows: $U B C>18 S>$ eIF- $4 \alpha>\beta-T U B>A C T>e E F-1 \alpha>G A P D H>$

$U B Q 10>U B Q 5>25 S$, whereas, in the Xoo group, the stability of the 10 candidate genes was as follows: $U B C>18 S>\beta$ $T U B>e I F-4 a>G A P D H>U B Q 10>U B Q 5>A C T>e E F-$

$1 a>25 S$. Thus, in both cases, the most stable genes were $U B C$ and $18 S$. In contrast, the gene $25 S$ showed the lowest stability in the water and Xoo groups. In the MT-water group, the expression stability of the 10 candidate genes ranked as follows: $U B Q 5>U B C>U B Q 10>e E F-1 \alpha>e I F-$ $4 \alpha>G A P D H>18 S>\beta-T U B>A C T>25 S$, whereas, in the MT-Xoo group, the stability of the 10 candidate genes ranked as follows: $U B Q 5>U B C>e E F-1 \alpha>e I F-4 \alpha>A C T>U B Q 10>$ $18 S>G A P D H>\beta-T U B>25 S$. Thus, $U B Q 5$ and $U B C$ were the most stably expressed genes under melatonin treatment. In general, $U B C$ was the most stably expressed gene across the four groups, and the $25 S$ was found to be the most unstably expressed gene.

In the Bestkeeper analysis, genes with the highest correlation coefficient $(r)$ and the lowest $\mathrm{SD}$ and $\mathrm{CV}$ values were considered as the most stably expressed. Genes with SD value greater than 1 were considered to be

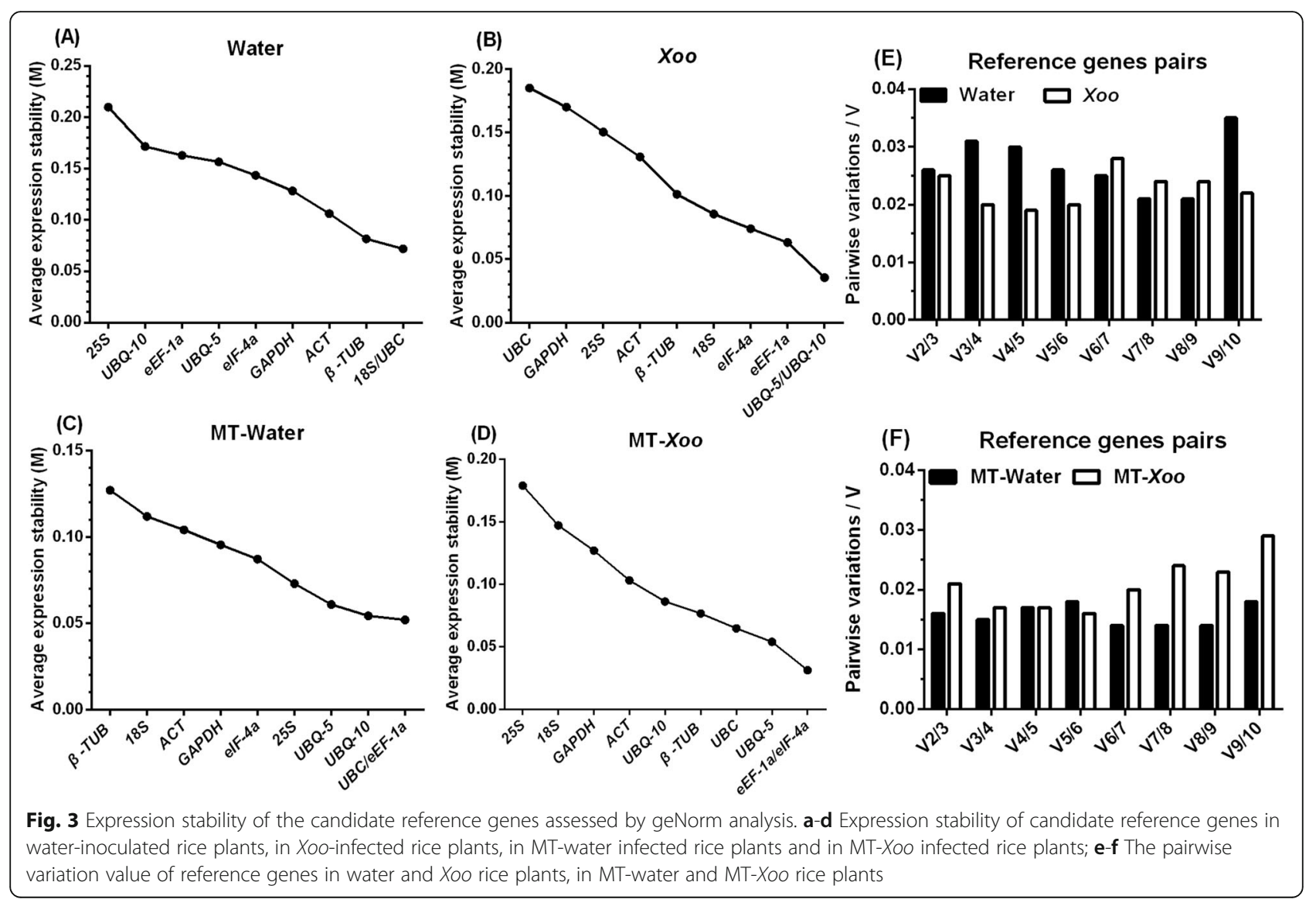




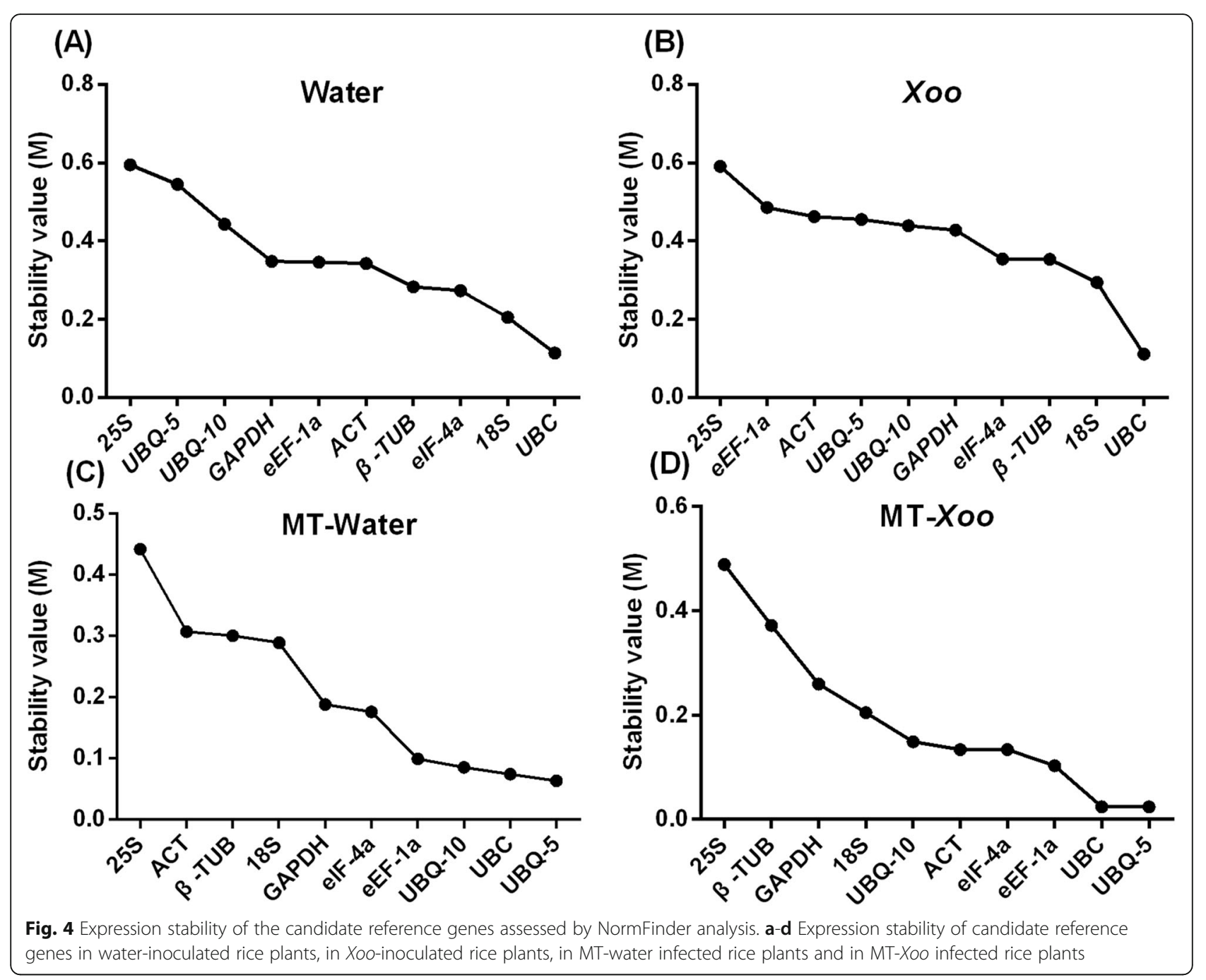

Table 3 Gene expression stability of 10 candidate reference genes calculated by Bestkeeper

\begin{tabular}{|c|c|c|c|c|c|c|c|c|c|c|c|c|}
\hline \multirow{2}{*}{$\begin{array}{l}\text { Gene } \\
\text { symbol }\end{array}$} & \multicolumn{3}{|c|}{ Water } & \multicolumn{3}{|c|}{$X_{00}$} & \multicolumn{3}{|c|}{ MT-Water } & \multicolumn{3}{|c|}{ MT-XoO } \\
\hline & $\overline{n^{a}}$ & $\mathrm{SD}( \pm \mathrm{Ct})$ & $\mathrm{CV}[\% \mathrm{Ct}]^{\mathrm{b}}$ & $\overline{n^{a}}$ & $\mathrm{SD}( \pm \mathrm{Ct})$ & $\mathrm{CV}[\% \mathrm{Ct}]^{\mathrm{b}}$ & $\overline{n^{a}}$ & $\mathrm{SD}( \pm \mathrm{Ct})$ & $\mathrm{CV}[\% \mathrm{Ct}]^{\mathrm{b}}$ & $\overline{n^{a}}$ & $\mathrm{SD}( \pm \mathrm{Ct})$ & $\mathrm{CV}[\% \mathrm{Ct}]^{\mathrm{b}}$ \\
\hline $18 \mathrm{~S}$ & 9 & 0.18 & 2.36 & 9 & 0.31 & 4.15 & 9 & 0.13 & 1.75 & 9 & 0.06 & 0.83 \\
\hline $25 S$ & 9 & 0.57 & 5.80 & 9 & 0.46 & 4.68 & 9 & 0.21 & 2.24 & 9 & 0.23 & 2.36 \\
\hline $\mathrm{ACT}$ & 9 & 0.23 & 1.24 & 9 & 0.37 & 1.93 & 9 & 0.24 & 1.22 & 9 & 0.18 & 0.91 \\
\hline$\beta$-TUB & 9 & 0.21 & 0.75 & 9 & 0.34 & 1.21 & 9 & 0.35 & 1.23 & 9 & 0.46 & 1.6 \\
\hline eEF1-a & 9 & 0.38 & 2.19 & 9 & 0.36 & 2.05 & 9 & 0.25 & 1.43 & 9 & 0.3 & 1.66 \\
\hline elF-4a & 9 & 0.32 & 1.53 & 9 & 0.34 & 1.63 & 9 & 0.31 & 1.48 & 9 & 0.32 & 1.51 \\
\hline UBC & 9 & 0.14 & 0.63 & 9 & 0.17 & 0.77 & 9 & 0.22 & 0.99 & 9 & 0.22 & 0.97 \\
\hline UBQ5 & 9 & 0.37 & 2.08 & 9 & 0.43 & 2.37 & 9 & 0.19 & 1.04 & 9 & 0.22 & 1.17 \\
\hline UBQ10 & 9 & 0.42 & 2.30 & 9 & 0.43 & 2.31 & 9 & 0.23 & 1.23 & 9 & 0.25 & 1.29 \\
\hline GADPH & 9 & 0.31 & 1.18 & 9 & 0.32 & 1.21 & 9 & 0.27 & 1.01 & 9 & 0.31 & 1.16 \\
\hline
\end{tabular}

${ }^{\text {a Number of samples }}$

${ }^{\mathrm{b}}$ Coefficient of variation expressed as the percentage of the $\mathrm{Ct}$ value 
unacceptable reference genes. As shown in Table 3, in the water group, the stability of the 10 candidate genes ranked as follows: $U B C>18 S>\beta-T U B>A C T>G A P D$ $H>e I F-4 \alpha>U B Q 5>e E F-1 \alpha>U B Q 10>25 S$; and, in the $X o o$ group, the stability of the 10 candidate genes ranked from $U B C>18 S>G A P D H>\beta-T U B>e I F-4 \alpha>e E F-1 \alpha>$ $A C T>U B Q 5>U B Q 10>25 S$. In both cases, $U B C$ and $18 S$, were the most stable. In the MT-water group, the stability of the 10 candidate genes ranked from $18 S>$ $U B Q 5>25 S>U B C>U B Q 10>A C T>e E F-1 \alpha>G A P D$ $H>$ eIF- $4 \alpha>\beta$-TUB; and, in the MT-Xoo group, the following order was detected: $18 S>A C T>U B C>U B Q 5>$ $25 S>U B Q 10>e E F-1 \alpha>$ GAPDH $>$ eIF- $4 \alpha>\beta-T U B$.

Thus, the most stably expressed genes were $18 S$ and $A C T$ in the MT-Xoo group, whereas $18 S$ and $U B Q 5$ were the most stable in the MT-water group. In this case, the results suggested that $18 S$ was the most stably expressed gene across the four groups (Tables 4 and 5).

The expression stability analysis using the three most common software algorithms, including geNorm, NormFinder and BestKeeper, gives a ranking of the candidate reference genes, but none of them is currently considered to be the best one (Robledo et al. 2014). The geNorm method ranks candidate reference genes mainly by their correlations, assuming that none of the above genes are co-regulated (Manjarin et al. 2011). If there is co-regulation between two genes, then geNormmay spoil the analysis. Since SD is a direct measure of variation, the BestKeeper method is considered to be of "common sense" to measure stability (Robledo et al. 2014). However, genes with a lower overall intergroup an intragroup variation still cannot be recognized as a good reference gene if this variation can not reflect the errors produced during the sample preparation steps. While if none of the candidate reference genes are co-regulated, then this above problem may be circumvented. Compared to geNorm and BestKeeper, the software algorithm of NormFinder relies on the intragroup and intergroup variation by using a different mathematical model. This helps NormFinder to avoid the drawback of co-regulated genes. In many cases, the application of geNorm and NormFinder yields very similar results. However, the candidate reference genes can't be recognized as good reference genes if there is a lower overall intergroup an intragroup variation. Hence, the advantages and disadvantages of these three methods should be taken into consideration when evaluating candidate reference genes.

Previous studies revealed that $18 \mathrm{~S}$ was the most stable reference gene for qRT-PCR in rice under various growth stages and times after UV-irradiation treatment (Kim et al. 2003). In agreement, $18 S$ was recognized as the most stable reference gene in rice under Xoo-infection and water treatment in this work. It was reported that $U B C$ was identified as the most unaltered reference gene under $R B S D V$ and $R S V$ treatments (Shen et al. 2014). Here, $U B C$ and $U B Q$ were the most reliable genes across all rice samples under Xoo infection and MT treatment, and the application of $U B C$ and $U B Q$ would provide more accurate comparison across samples by qRT-PCR.

\section{Conclusions}

To the best of our knowledge, this is the first report on evaluation of suitable candidate reference genes for normalization of gene expression of $\mathrm{qRT}-\mathrm{PCR}$ in rice under MT supplementation. In this work, we tested 10 common used candidate reference genes. We found that

Table 4 Ranking of the candidate reference genes according to their stability value calculated using geNorm, Normfinder and Bestkeeper in PX099-infected rice plant

\begin{tabular}{|c|c|c|c|c|c|c|c|c|c|c|c|c|}
\hline \multirow{3}{*}{$\begin{array}{l}\text { Sample } \\
\text { Genes }\end{array}$} & \multicolumn{6}{|l|}{ Water } & \multicolumn{6}{|l|}{ Xoo } \\
\hline & \multicolumn{2}{|c|}{ BestKeeper } & \multicolumn{2}{|l|}{ gerNorm } & \multicolumn{2}{|c|}{ Normfinder } & \multicolumn{2}{|c|}{ BestKeeper } & \multicolumn{2}{|l|}{ gerNorm } & \multicolumn{2}{|c|}{ Normfinder } \\
\hline & $\mathrm{M}$ value & $\begin{array}{l}\text { Rank } \\
\text { Order }\end{array}$ & $\mathrm{M}$ value & Rank Order & M value & Rank Order & M value & Rank Order & $\mathrm{M}$ value & Rank Order & M value & Rank Orde \\
\hline $18 \mathrm{~S}$ & 0.18 & 2 & 0.071812 & 1 & 0.205 & 2 & 0.31 & 2 & 0.085747 & 4 & 0.294 & 2 \\
\hline $25 S$ & 0.57 & 10 & 0.209846 & 9 & 0.595 & 10 & 0.46 & 8 & 0.150497 & 7 & 0.591 & 10 \\
\hline ACT & 0.23 & 4 & 0.106165 & 3 & 0.342 & 5 & 0.37 & 6 & 0.130881 & 6 & 0.462 & 8 \\
\hline$\beta-T U B$ & 0.21 & 3 & 0.081461 & 2 & 0.282 & 4 & 0.34 & 4 & 0.101257 & 5 & 0.353 & 3 \\
\hline eEF1-a & 0.38 & 8 & 0.16297 & 7 & 0.346 & 6 & 0.36 & 5 & 0.063164 & 2 & 0.486 & 9 \\
\hline elF-4a & 0.32 & 6 & 0.143502 & 5 & 0.273 & 3 & 0.34 & 4 & 0.074115 & 3 & 0.354 & 4 \\
\hline UBC & 0.14 & 1 & 0.071812 & 1 & 0.114 & 1 & 0.17 & 1 & 0.184964 & 9 & 0.111 & 1 \\
\hline UBQ5 & 0.37 & 7 & 0.156697 & 6 & 0.545 & 9 & 0.43 & 7 & 0.035446 & 1 & 0.455 & 7 \\
\hline UBQ10 & 0.42 & 9 & 0.17176 & 8 & 0.443 & 8 & 0.43 & 7 & 0.035446 & 1 & 0.439 & 6 \\
\hline GADPH & 0.31 & 5 & 0.128316 & 4 & 0.348 & 7 & 0.32 & 3 & 0.16996 & 8 & 0.428 & 5 \\
\hline
\end{tabular}


Table 5 Ranking of the candidate reference genes according to their stability value calculated using geNorm, Normfinder and Bestkeeper in PX099-infected rice plant under MT treatments

\begin{tabular}{|c|c|c|c|c|c|c|c|c|c|c|c|c|}
\hline \multirow{3}{*}{$\begin{array}{l}\text { Sample } \\
\text { Genes }\end{array}$} & \multicolumn{6}{|c|}{ MT-Water } & \multicolumn{6}{|l|}{ MT-Хoo } \\
\hline & \multicolumn{2}{|c|}{ BestKeeper } & \multicolumn{2}{|l|}{ gerNorm } & \multicolumn{2}{|c|}{ Normfinder } & \multicolumn{2}{|c|}{ BestKeeper } & \multicolumn{2}{|l|}{ gerNorm } & \multicolumn{2}{|c|}{ Normfinder } \\
\hline & M value & Rank Order & M value & Rank Order & $M$ value & Rank Order & M value & Rank Order & M value & Rank Order & M value & Rank Order \\
\hline 185 & 0.13 & 1 & 0.112076 & 8 & 0.289 & 7 & 0.06 & 1 & 0.147335 & 8 & 0.205 & 7 \\
\hline $25 S$ & 0.21 & 3 & 0.073051 & 4 & 0.442 & 10 & 0.23 & 4 & 0.179034 & 9 & 0.489 & 10 \\
\hline $\mathrm{ACT}$ & 0.24 & 6 & 0.104181 & 7 & 0.307 & 9 & 0.18 & 2 & 0.103178 & 6 & 0.134 & 5 \\
\hline$\beta-T U B$ & 0.35 & 10 & 0.127072 & 9 & 0.3 & 8 & 0.46 & 9 & 0.076681 & 4 & 0.372 & 9 \\
\hline eEF1-a & 0.25 & 7 & 0.051968 & 1 & 0.099 & 4 & 0.3 & 6 & 0.031131 & 1 & 0.103 & 3 \\
\hline elF-4a & 0.31 & 9 & 0.087268 & 5 & 0.176 & 5 & 0.32 & 8 & 0.031131 & 1 & 0.134 & 4 \\
\hline UBC & 0.22 & 4 & 0.051968 & 1 & 0.074 & 2 & 0.22 & 3 & 0.064671 & 3 & 0.024 & 2 \\
\hline UBQ5 & 0.19 & 2 & 0.060874 & 3 & 0.063 & 1 & 0.22 & 3 & 0.053811 & 2 & 0.024 & 1 \\
\hline UBQ10 & 0.23 & 5 & 0.054308 & 2 & 0.085 & 3 & 0.25 & 5 & 0.086203 & 5 & 0.149 & 6 \\
\hline GADPH & 0.27 & 8 & 0.095592 & 6 & 0.188 & 6 & 0.31 & 7 & 0.127123 & 7 & 0.26 & 8 \\
\hline
\end{tabular}

some reference genes were unstably expressed under the studied conditions. However, we observed that $18 S+$ $U B C$ and $U B Q 5+U B C$ were the most reliable reference genes in Xoo infection and simultaneous MT supplementation with Xoo infection, respectively. These fundamental but vital outcomes will facilitate the gene expression studies of related biological processes, and will help to better understand MT-induced signal pathways in rice plants.

\section{Abbreviations}

MT: Melatonin; Xoo: Xanthomonasoryzaepv. oryzae; 18S: 185 ribosomal RNA; 25S: 25 S ribosomal RNA; UBQ5: Ubiquitin 5; UBQ10: Ubiquitin 10; ACT: Actin; $\beta$ TUB: $\beta$-Tubulin; eEF-1a: Eukaryotic elongation factor 1-alpha; elF-4a: Eukaryotic initiation factor 4-alpha; UBC: Ubiquitin-conjugating enzyme E2; GAPD H: Glyceraldehyde-3-phosphate dehydrogenase; qRT-PCR: Quantitative real-time PCR; TTSS: Type III protein secretion system; DEGs, differential expressed genes; PRs: Pathogenesis-related proteins; NB, nutrient broth; NA: Nutrient broth with agar; UV: Ultraviolet; E value: Efficiency of amplification curves; Ct: Cycle threshold; $\mathrm{R}^{2}$ : Correlation coefficient; SD: Standard deviation; CV: Coefficient of variance; SV: Stability value; Cq: Cycle quantification value; RBSDV: Rice Black-Streaked Dwarf Virus; RSV: Rice Strip Virus

\section{Acknowledgements}

We want to thank the Natural Science Foundation of Jiangsu Province of China, Agro-scientific Research in the Public Interest, the National Natural Science Foundation of China and the National Key R\&D Program of China for supporting this project.

\section{Authors' contributions}

$F L$ and $X C$ designed the study; $X C$ and YD performed the experiments; $X C$ and YD analyzed the data; $X C$ drafted the manuscript; FL and PL reviewed and edited the manuscript. The author(s) read and approved the final manuscript.

\section{Funding}

This research was supported by grants from the State Key Laboratory for Managing Biotic and Chemical Threats to the Quality and Safety of Agroproducts (2010DS700124-KF2007). the National Natural Science Foundation of China (31571974), the Special Fund for Agro-scientific Research in the Public Interest (201303015), the National Key R\&D Program of China (2017YFD0200900) and the Natural Science Foundation of Jiangsu Province of China (BK20170606)

\section{Availability of data and materials}

Please contact authors for data request.

\section{Competing interests}

The authors declare that they have no competing interests.

\section{Author details}

${ }^{1}$ Institute of Plant Protection,Jiangsu Key Laboratory for Food Quality and Safety-State Key Laboratory Cultivation Base of Ministry of Science and Technology, Jiangsu Academy of Agricultural Sciences, Nanjing 210014, PR China. ${ }^{2}$ State Key Laboratory for Managing Biotic and Chemical Threats to the Quality and Safety of Agro-products, Zhejiang Academy of Agricultural Sciences, Hangzhou 310021, PR China. ${ }^{3}$ School of Life Sciences, Nantong University, Nantong 226019, PR China.

Received: 23 March 2020 Accepted: 26 August 2020

Published online: 24 September 2020

\section{References}

Andersen, C. L., Jensen, J. L., \& Orntoft, T. F. (2004). Normalization of real-time quantitative reverse transcription-PCR data: a model-based variance estimation approach to identify genes suited for normalization, applied to bladder and colon cancer data sets. Cancer Research, 64, 5245-5250.

Bi, J. A., Yang, Y., Chen, B., Zhao, J., Chen, Z., Song, B., et al. (2019). Retardation of the Calvin cycle contributes to the reduced $\mathrm{CO}_{2}$ assimilation ability of rice stripe virus-infected $N$. benthamiana and suppresses viral infection. Front Microbiology, 10, 568.

Bustin, S., \& Nolan, T. (2017). Talking the talk, but not walking the walk: RT-qPCR as a paradigm for the lack of reproducibility in molecular research. European Journal of Clinical Investigation, 47, 756-774.

Chen, X., Laborda, P., \& Liu, F. Q. (2020). Exogenous melatonin enhances rice plant resistance against Xanthomonas oryzae pv. Oryzae. Plant Disease, 104, $1701-1708$.

Chen, X., Sun, C., Laborda, P., He, Y., Zhao, Y., Li, Z., \& Liu, F. (2019). Melatonin treatments reduce the pathogenicity and inhibit the growth of Xanthomonas oryzae pv. oryzicola. Plant Pathology, 68, 288-296.

Chen, X., Sun, C., Laborda, P., Zhao, Y., Palmer, I., Fu, Z., et al. (2018). Melatonin treatment inhibits the growth of Xanthomonas oryzae pv. oryzae. Frontiers in Microbiology, 9, 2280.

Chomczynski, P., \& Mackey, K. (1995). Short technical reports. Modification of the TRI reagent procedure for isolation of RNA from polysaccharide- and proteoglycan-rich sources. Biotechniques, 19, 942-945.

Jain, M., Nijhawan, A., Tyagi, A. K., \& Khurana, J. P. (2006). Validation of housekeeping genes as internal control for studying gene expression in rice by quantitative real-time PCR. Biochemical and Biophysical Research Communications, 345, 646-651. 
Kauffman, H., Reddy, A., Hsieh, S., \& Merca, S. (1973). Improved technique for evaluating resistance of rice varieties to Xanthomonas oryzae. Plant Disease Reporter, 57, 537-541.

Kim, B. R., Nam, H. Y., Kim, S. U., Kim, S. I., \& Chang, Y. J. (2003). Normalization of reverse transcription quantitative-PCR with housekeeping genes in rice. Biotechnology Letters, 25, 1869-1872.

Laborda, P., Chen, X., Wu, G., Wang, S., Lu, X., Ling, J., et al. (2020). Lysobacter gummosus $\mathrm{OH} 17$ induces disease resistance systemic resistance in Oryza sativa 'Nipponbare'. Plant Pathology, 69, 838-848.

Li, Q., Lu, J., Zhou, Y., Wu, F., Tong, H., Wang, J., et al. (2019). Abscisic acid represses rice lamina joint inclination by antagonizing brassinosteroid biosynthesis and signaling. International Journal of Molecular Sciences, 20, 4908.

Li, Q., Sun, S., Yuan, D., Yu, H., Gu, M., \& Liu, Q. (2010). Validation of candidate reference genes for the accurate normalization of real-time quantitative RTPCR data in rice during seed development. Plant Molecular Biology Reporter 28,49 .

Li, T., Wu, Q., Zhu, H., Zhou, Y., Jiang, Y., Gao, H., \& Yun, Z. (2019b). Comparative transcriptomic and metabolic analysis reveals the effect of melatonin on delaying anthracnose incidence upon postharvest banana fruit peel. BMC Plant Biology, 19, 289

Liang, C., Zheng, G., Li, W., Wang, Y., Hu, B., Wang, H., et al. (2015). Melatonin delays leaf senescence and enhances salt stress tolerance in rice. Journal of Pineal Research, 59, 91-101.

Manjarin, R., Trottier, N. L., Weber, P. S., Liesman, J. S., Taylor, N. P., \& Steibel, J. P. (2011). A simple analytical and experimental procedure for selection of reference genes for reverse-transcription quantitative PCR normalization data. Journal of Diary Science, 94, 4950-4961.

Pfaffl, M. W., Tichopad, A., Prgomet, C., \& Neuvians, T. P. (2004). Determination of stable housekeeping genes, differentially regulated target genes and sample integrity: BestKeeper--excel-based tool using pair-wise correlations. Biotechnology Letters, 26, 509-515.

Pfeilmeier, S., Caly, D. L., \& Malone, J. G. (2016). Bacterial pathogenesis of plants: Future challenges from a microbial perspective: Challenges in bacterial molecular plant pathology. Molecular Plant Pathology, 17, 1298-1313.

Robledo, D., Hernandez-Urcera, J., Cal, R. M., Pardo, B. G., Sanchez, L., Martinez, P., $\&$ Vinas, A. (2014). Analysis of qPCR reference gene stability determination methods and a practical approach for efficiency calculation on a turbot (Scophthalmus maximus) gonad dataset. BMC Genomics, 15, 648.

Rutledge, R. G., \& Stewart, D. (2008). Critical evaluation of methods used to determine amplification efficiency refutes the exponential character of realtime PCR. BMC Molecular Biology, 9, 96.

Shen, G., Jiang, H., Wang, X., \& Wang, J. (2010). Evaluation of endogenous references for gene expression profiling in different tissues of the oriental fruit fly Bactrocera dorsalis (Diptera: Tephritidae). BMC Molecular Biology, 11, $76-76$.

Shen, J., Li, J., Sun, L., \& Chen, J. (2014). Reference gene selection for real-time fluorescence quantitative PCR analysis in rice plants infected by Rice blackstreaked dwarf virus or Rice stripe virus. Acta Phytopathologica Sinica, 44, 276-286.

Sheshadri, S. A., Nishanth, M. J., Yamine, V., \& Simon, B. (2018). Effect of melatonin on the stability and expression of reference genes in Catharanthus roseus. Scientific Reports, 8, 2222.

Silveira, É. D., Alves-Ferreira, M., Guimarães, L. A., da Silva, F. R., \& Carneiro, V. T. D. $C$. (2009). Selection of reference genes for quantitative real-time PCR expression studies in the apomictic and sexual grass Brachiaria brizantha. BMC Plant Biology, 9, 84

Srivastava, N., Chaudhary, S., Kumar, V., Katudia, K., Vaidya, K., Vyas, M. K., \& Chikara, S. K. (2012). Evaluation of the yield, quality and integrity of total RNA extracted by four different extraction methods in rice (Oryza sativa). Journal of Crop Science and Technology, 1, 1-9.

Sundaram, V. K., Sampathkumar, N. K., Massaad, C., \& Grenier, J. (2019). Optimal use of statistical methods to validate reference gene stability in longitudinal studies. PLoS One, 14, e0219440.

Tariq, R., Ji, Z., Wang, C., Tang, Y., Zou, L., Sun, H., et al. (2019). RNA-Seq analysis of gene expression changes triggered by Xanthomonas oryzae pv. oryzae in a susceptible rice genotype. Rice, 12, 44.

Vandesompele, J., De Preter, K., Pattyn, F., Poppe, B., Van Roy, N., De Paepe, A., \& Speleman, F. (2002). Accurate normalization of real-time quantitative RT-PCR data by geometric averaging of multiple internal control genes. Genome Biology, 3, 34
Wang, S., Shi, X., \& Laborda, P. (2020). Indole-based melatonin analogues: Synthetic approaches and biological activity. European Journal of Medicinal Chemistry, 185, 11847

Wang, X., Zhou, J., Yang, Y., Yu, F., Chen, J., Yu, C., et al. (2012). Transcriptome analysis of a progeny of somatic hybrids of cultivated rice (Oryza sativa L.) and wild rice (Oryza meyeriana L.) with high resistance to bacterial blight. Journal of Phytopathology, 161, 324-334.

Wei, Y., Zeng, H., Hu, W., Chen, L., He, C., \& Shi, H. (2016). Comparative transcriptional profiling of melatonin synthesis and catabolic genes indicates the possible role of melatonin in developmental and stress responses in rice. Frontiers in Plant Science, 7,676.

White, F. F., \& Yang, B. (2009). Host and pathogen factors controlling the riceXanthomonas oryzae interaction. Plant Physiology, 150, 1677-1686.

Yang, X., Pan, H., Yuan, L., \& Zhou, X. (2018). Reference gene selection for RTqPCR analysis in Harmonia axyridis, a global invasive lady beetle. Scientific Reports, 8, 2689.

Yuan, M., Chu, Z., Li, X., Xu, C., \& Wang, S. (2010). The bacterial pathogen Xanthomonas oryzae overcomes rice defenses by regulating host copper redistribution. Plant Cell, 22, 3164-3176.

Zhao, Z., Zhang, Z., Ding, Z., Meng, H., Shen, R., Tang, H., et al. (2019). Publictranscriptome-database-assisted selection and validation of reliable reference genes for qRT-PCR in rice. Science China Life Sciences, 63, 92-101.

\section{Publisher's Note}

Springer Nature remains neutral with regard to jurisdictional claims in published maps and institutional affiliations.
Ready to submit your research? Choose BMC and benefit from:

- fast, convenient online submission

- thorough peer review by experienced researchers in your field

- rapid publication on acceptance

- support for research data, including large and complex data types

- gold Open Access which fosters wider collaboration and increased citations

- maximum visibility for your research: over $100 \mathrm{M}$ website views per year

At BMC, research is always in progress.

Learn more biomedcentral.com/submissions 